\title{
Is innovative firm behavior correlated with age and gender composition of the workforce? Evidence from a new type of data for German enterprises
}

\author{
Christian Pfeifer · Joachim Wagner
}

Published online: 26 July 2013

(C) Institut für Arbeitsmarkt- und Berufsforschung 2013

\begin{abstract}
This empirical research note documents the relationship between composition of a firm's workforce (with a special focus on age and gender) and its performance with respect to innovative activities (outlays and employment in research and development $(\mathrm{R} \& \mathrm{D})$ ) for a large representative sample of enterprises from manufacturing industries in Germany using unique newly available data. We find that firms with a higher share of older workers have significantly lower proportions of $\mathrm{R} \& \mathrm{D}$ outlays in total revenues and of
\end{abstract}

This paper is part of the project KombiFiD - Kombinierte

Firmendaten für Deutschland that is financially supported by the German Ministry for Education and Research (BMBF). It is a joint project of the Institute of Economics of Leuphana University Lueneburg, the research data centres of the German Federal Statistical Office and the statistical offices of the German federal states, the Institute of Employment Research of the Federal Employment Agency and the research department of the German Central Bank. While members of the KombiFiD-team from all institutions contributed to the construction of the data set used in this paper we alone are responsible for the study presented here and the conclusions drawn. We thank Alexander Vogel for help with the data and two reviewers for helpful comments. For details on how to access the KombiFiD data see www.kombifid.de. To facilitate replication the Stata do-file is available from the authors on request. Pfeifer thanks the VolkswagenStiftung for financial support.

Prof. Dr. J. Wagner

CESIS, Stockholm, Sweden

Prof. Dr. C. Pfeifer · Prof. Dr. J. Wagner $(\bowtie)$

Institute of Economics, Leuphana University Lueneburg,

P.O. Box 2440, 21314 Lueneburg, Germany

e-mail: wagner@leuphana.de

Prof. Dr. C. Pfeifer

e-mail: pfeifer@leuphana.de

Prof. Dr. C. Pfeifer · Prof. Dr. J. Wagner

IZA, Bonn, Germany
R\&D employment in total employment, whereas firms with a higher share of female employment seem to be more active in $\mathrm{R} \& \mathrm{D}$.

Keywords Ageing - Firm performance - Gender · Germany $\cdot$ Innovation $\cdot R \& D$

JEL Classification D22 - D24 · J21 · J24 - L25

Besteht ein Zusammenhang zwischen dem Innovationsverhalten von Firmen und der Alters- und Geschlechtsstruktur der Belegschaft? Empirische Befunde auf der Basis einer neuen Art von Daten für deutsche Unternehmen

Zusammenfassung Dieser kurze empirische Beitrag dokumentiert den Zusammenhang zwischen der Zusammensetzung der Belegschaft eines Unternehmens (mit einem speziellen Fokus auf Alter und Geschlecht der Beschäftigten) und den Innovationsaktivitäten der Firma (gemessen anhand der Aufwendungen für Forschung und Entwicklung (FuE) und der Beschäftigten in diesem Bereich) auf der Grundlage neu verfügbarer Daten für eine umfangreiche Stichprobe von Industrieunternehmen in Deutschland. Wir finden, dass Firmen mit einem höheren Anteil älterer Arbeitnehmer einen signifikant niedrigeren Anteil der FuE-Ausgaben am Umsatz und der FuE-Beschäftigten an allen Beschäftigten aufweisen, während Firmen mit einem höheren Anteil weiblicher Beschäftigter in FuE aktiver sind.

\section{Introduction}

Innovative activities are important for the performance of firms and the growth of the economy as a whole. This holds 
especially for firms from manufacturing industries in Germany. The manufacturing sector is known to be highly export intensive, and Germany is one of the leading actors on the world market for goods. International competitiveness of manufacturing firms depends to a high degree on the capability of firms to supply high-quality innovative products (see Wagner 2011). Therefore, research and development (R\&D) activities that are important for continuous improvements of products and production processes are a decisive factor for the success of firms. That said, information on factors that are positively or negatively related to $R \& D$ activities of firms is important for both researchers and policy makers. This paper focuses on one aspect that is becoming more and more important not only for Germany but for other highly industrialized countries, too- the consequences of an ageing population and an ageing workforce for innovation activities of firms.

The effects of an aging workforce are usually analyzed in the context of productivity estimates that mostly indicate a negative effect of the oldest age groups on firm performance (see Pfeifer and Wagner 2012 for a review). In the context of innovations, we should also expect a negative correlation with age, because the literature about age-dependent skill formation suggests that age has a negative effect on human capital investments (e.g., due to decreasing amortization periods) and on cognitive skills such as intelligence, memory power, reasoning, creativity, and fluid problem-solving skills (e.g., Kaufman 2001; Pfeiffer and Reuß 2008), which are important for innovative activities. Previous studies, which use firm level data, find indeed that (old) age has a negative effect on firms' innovation activities (e.g., product and process innovations, patents) (e.g., Schneider 2008 for Germany, Parrotta et al. 2012 for Denmark). The demographic change makes it also necessary to activate female labor supply. In order to analyze the effect of female employment on innovative activities, we include in our regression analysis the gender composition of a firm's workforce in addition the age composition of the workforce. We extend the literature by using newly available high quality official data for Germany. In addition to largely unbiased data obtained from administrative sources, the data set contains unique information such as the proportion of R\&D outlays in total revenues that has not been previously studied. One drawback of our empirical analyses is, however, that we cannot rule out endogeneity problems such as reverse causality. Therefore, we can only look at the correlation between innovative firm behavior and the age and gender composition of the workforce. This limitation should be kept in mind when putting the results into perspective.

The remainder of the paper is structured as follows. The next section informs about the data and the estimation strategy. Section 3 presents the results of our fractional logit estimates. The paper concludes with a short summary in Sect. 4.

\section{Data and estimation strategy}

The empirical investigation uses data for enterprises ${ }^{1}$ from manufacturing industries that come from two sources. The first source is the cost structure survey for enterprises in the manufacturing sector. This survey is carried out annually by the statistical offices as a representative random sample survey stratified according to the number of employees and the industries (see Fritsch et al. 2004). The sample covered by the cost structure survey represents all enterprises with at least 20 employees from manufacturing industries. About 45 percent of the enterprises with 20 to 499 employees and all enterprises with 500 and more employees are included in the sample. ${ }^{2}$ While firms with 500 and more employees are covered by the cost structure survey in each year, the sample of smaller firms is part of the survey for four years in a row only. This survey is the source for information on innovative behavior, firm size and industry affiliation:

We measure innovative firm behavior by two outcome variables. The first innovation variable is the proportion of $R \& D$ outlays in total revenues. The second innovation variable is the share of workers in $R \& D$ in total employment. These two R\&D variables are direct measures of innovative firm behavior - they indicate the orientation of the firm towards innovative activities. These R\&D activities can be regarded as inputs into the generation of new knowledge that leads to new improved products and/or production processes. Evidently, firms can introduce new products and new production processes without any in-house R\&D activities by buying licenses from other firms. And there is a certain amount of randomness in the link between innovation input $(\mathrm{R} \& \mathrm{D})$ and innovation output (new products, new production processes). $R \& D$ projects can fail to produce innovations. Empirically, $R \& D$ activities and innovations in a firm are positively linked. Therefore, the two measures of $R \& D$ activities used here can be considered as valid indicators for innovative firm behavior. ${ }^{3}$

\footnotetext{
${ }^{1}$ Data are for legal units (enterprises, or Unternehmen), not for local production units (establishments, or Betriebe). In this paper we use the term firm as a synonym for enterprise.

${ }^{2}$ For details see the quality report for the cost structure survey published by the Federal Statistical Office that is available on the web: http://www.destatis.de/jetspeed/portal/cms/Sites/destatis/Internet/DE/ Content/Publikationen/Qualitaetsberichte/Verarbeitendes GewerbeIndustrie/Kostenstruktur,property=file.pdf.

${ }^{3}$ The seminal conceptual framework by Crépon et al. (1998) on research, innovation and productivity is made of three parts. The first describes the firms' choice of innovation inputs $(R \& D)$ as a function of firm and industry variables; the second (often termed a knowledge production function) links R\&D (inputs) to innovations (output); the third links innovations to firm performance (sales, profits, productivity). Our paper can be viewed as an attempt to investigate the first part of this model. See Roberts and Vuong (2013) for a discussion of the full model and related literature. Roberts and Vuong (2013) estimate a dynamic structural model of $\mathrm{R} \& \mathrm{D}$, innovations and productivity with
} 
Firm size is measured by the number of people working in a firm. This variable is included to control for unobserved firm characteristics that can be expected to be correlated with innovative behavior. These unobserved firm characteristics include firm age (larger firms tend to be older), financial constraints (small firms tend to have more difficulties to raise funds for risky $R \& D$ projects) and management quality (larger firms tend to have grown at a higher rate in the past and, therefore, will have a better management that might be more inclined to innovate). Therefore, we expect a ceteris paribus positive relationship between firm size and innovative activities. This positive nexus might be nonlinear and decreasing, and the squared number of employees is included in the empirical models to take care of this.

Industry affiliation of a firm is recorded at the two-digit level. The industry dummy variables are included to control for unobserved industry specific demand shocks, regulatory measures and opportunities to innovate that can be expected to influence the R\&D behavior of firms. Furthermore, industry affiliation is a proxy variable (although a rather crude one) for differences in the capital intensity that cannot be measured with the data at hand.

The second source of data is the Establishment History Panel (Betriebs-Historik-Panel) ${ }^{4}$ Details aside, this data set is built from individual level information for employees covered by social security. ${ }^{5}$ In a first step for each year from 1975 onwards information for all employees working in a local production unit (establishment) was aggregated, and this is the standard version of the Establishment History Panel. In this study we use a different version of the Establishment History Panel. Here for multi-establishment enterprises information from all establishments of the enterprise was aggregated in a second step. The result is a data set with detailed information about the characteristics of the employees (covered by social security) in each enterprise in a year. Information reported to the social security system includes, among others, the sex of a person, the age and the qualification (educational level attained and vocational training concluded) ${ }^{6}$

German firm level data. They find that R\&D investment has substantial effects on the probability a firm realizes a product of process innovation (and that these innovations do have positive effects on firm productivity).

${ }^{4}$ For an introduction to the Establishment History Panel see Spengler (2008); a detailed description of the current version is Hethey-Maier and Seth (2010)

5 "All employees who are subject to at least one of the following compulsory insurances are liable to social security: health insurance, longterm care insurance, pension insurance, unemployment and accident insurance. However, not liable to social security and thus not included in the data are civil servants, conscripts, those doing alternative civilian service, self-employed, judges, scholars, students, pensioners, clergy and others." (Spengler 2008, p. 502).

${ }^{6}$ The cost structure survey for enterprises in the manufacturing sector is conducted by the German statistical offices. The data can be accessed
Share of employees from a certain age group is defined as the total number of employees (covered by social security) from the respective age group over the total number of employees (covered by social security) in an enterprise; the share is measured as a percentage.

Share of female employees is defined as the total number of females (covered by social security) over the total number of employees (covered by social security) in an enterprise; the share is measured as a percentage.

Share of medium qualified employees is defined as the total number of employees (covered by social security) with either the high-school diploma (Abitur) as the highest educational level attained or with vocational training concluded over the total number of employees (covered by social security) in an enterprise; the share is measured as a percentage.

Share of highly qualified employees is defined as the total number of employees with a polytech or university degree over the total number of employees (covered by social security) in an enterprise; the share is measured as a percentage. ${ }^{7}$

Share of part-time employees is defined as the total number of employees in part-time over the total number of employees (covered by social security) in an enterprise; the share is measured as a percentage.

Linking these confidential firm level information across the borders of the data producers, however, is difficult. Details aside, it is technically not easy (but not impossible either) and it is legal only if the firm agreed in written form. The basic idea of the project KombiFiD (an acronym that stands for Kombinierte Firmendaten für Deutschland, or combined firm level data for Germany) that is in detail described on the web (see www.kombifid.de) is to ask a large sample of firms from all parts of the German economy to agree to match confidential micro data for these firms that are kept separately by three data producers (the Statistical Offices, the Federal Employment Agency, and the German Central Bank) in one data set. Matching was performed inside the research data centers of the data producing agencies. Details of the matching process for the data from the Cost Structure Survey and the Establishment History Panel are discussed in Biewen et al. (2012). The matched data set can be considered as high-quality data that are free from severe selection problems. These matched data are made available

for scientific research via the Research Data Centres of the Federal Statistical Office and the Statistical Offices of the Federal States (see Zühlke et al. 2004). The Establishment History Panel is build from administrative data by the Research Data Centre of the Federal Employment Agency at the Institute for Employment Research. The data can be accessed via this Research Data Centre for scientific research (see Spengler 2008).

${ }^{7}$ Note that this information on the diversity of the employees is not available in more detail; for example, the number of female employees aged 30 to 34 with a university degree is not available from the data (although it would be possible to compute this figure from the individual level information available). 
for scientific research while strictly obeying the data protection law, i.e. without revealing micro level information to researchers outside the data producing agencies. In KombiFiD 54,960 firms were asked to agree in written form to merge firm level data from various surveys and administrative data for the reporting years 2003 to 2006. 30,944 firms replied and 16,571 agreed. These 16,571 firms are in the KombiFiD Agreement Sample. Access to the data is easy and costless (for details, see www.kombifid.de). The data are of a high quality, and participation of the enterprises in the cost structure survey and in the delivery of information on the employees covered by social security is mandated. Instead of opinions and "guesstimates" collected in surveys with voluntary participation, the KombiFiD-Data have reliably information on variables like revenues that are difficult to collect in interviews or questionnaires without mandatory participation. Therefore, the KombiFiD-Data should at least be carefully looked at by researchers from various fields in economics (including labor economics, industrial organization and international economics) interested in working with firm level data.

The sample of enterprises used in the empirical investigation performed here consists of all firms from manufacturing industries in West Germany in the KombiFiD Agreement Sample for which information from both data sources-the cost structure survey and the Establishment History Panelcould be linked in the KombiFiD project. Enterprises that do not have complete information for each year from 2003 to 2006 were dropped from the computations. The sample is limited to firms from West Germany. There are large differences between enterprises from West Germany and the former communist East Germany even many years after the unification in 1990. Therefore, an empirical study should be performed separately for both parts of Germany. The KombiFiD Agreement Sample for East German manufacturing firms, however, contains only a small number of firms, and this sample turned out to be not representative for the population of firms in a replication study that compares results based on the complete cost structure survey data and data from the KombiFiD Agreement Sample (see Wagner 2012).

Firms with incomplete information for any variable in at least one year were dropped from all computations because there are, on the one hand, by construction no entries due to the fact that the firms taking part in the cost structure survey were sampled before the start of the survey in 2003. On the other hand, exits cannot be identified because firms with information in, say, 2003 but not in 2004 might have closed down - they might have, however, relocated out of manufacturing (or out of Germany) or they might have shrunk below the cut-off point relevant for the cost-structure survey. This leads to a balanced panel data set with 16,900 observations for 4,225 firms and 4 years.
It should be pointed out that due to the fact that only 16,571 firms of 54,960 firms that were asked to do so agreed to take part in the KombiFiD project selectivity issues might be important. Unfortunately, we cannot perform a non-response analysis here. The reason for the absence of a formal selectivity analysis is that we are not allowed to perform such a study for legal reasons - if a firm did not agree to participate in the KombiFiD project it is strictly forbidden by data protection law to use any information from this firm in the project, including the information that the firm was not willing to participate. As a workaround a replication study was performed that compares the distributional characteristics of firms in the original sample and in the Komb$i F i D$ agreement sample, and that uses both data sets to estimate identically specified empirical models (see Wagner 2012). This study shows that results from empirical investigations for enterprises from West Germany (but not from East Germany) based on the KombiFiD sample are very similar to results computed with the original data. Therefore, the KombiFiD sample can be regarded as a sound data base for empirical studies on West German firms from manufacturing industries.

Descriptive statistics for all variables and the pooled data are reported in Table 1. It is evident from these descriptive statistics that the variation of the variables over the four years covered is very small when compared to the variation between the firms in the sample. Therefore, the within firm variation of important dimensions of diversity of the employees over time cannot be used in fixed effects models to sufficiently identify any relationship between changes in firm innovation proxies over time and diversity of employees.

Our outcome variables of interest are the proportion of R\&D outlays in total revenues and the share of workers in $\mathrm{R} \& \mathrm{D}$ in total employment as proxies for innovative firm behavior. Both variables are highly positively correlated in each year with a correlation coefficient that increases over time from 0.73 (in 2003) to 0.83 (in 2006). Both variables are censored, as their values are bound between zero and one. About 38 percent of our observations report a positive proportion of R\&D outlays in total revenues and about 37 percent a positive share of workers in R\&D in total employment as proxies for innovative firm behavior. In order to deal with fractions of this kind, we apply fractional logit regressions with robust standard errors clustered at the firm level, which have been proposed by Papke and Wooldridge (1996) and are normally used for this kind of dependent variables. ${ }^{8}$

\footnotetext{
${ }^{8}$ In our econometric investigation we choose a one-part model over a two-part model because we view the decision of how much to invest in R\&D activities (either by spending on R\&D or by employing people to do $R \& D$ ) as the outcome of a profit maximization problem solved by the firm. The firm does not decide whether to engage in R\&D at all or not in a first step, and then decide how much to spend on R\&D in
} 
Table 1 Descriptive statistics

\begin{tabular}{lcrr}
\hline Variables & Pooled mean & \multicolumn{2}{l}{ Standarddeviation } \\
\cline { 3 - 4 } & & Overall & Between \\
\hline Data from the Cost Structure Survey: & & & Within \\
Proportion of R\&D outlays in total revenues & 0.0111 & 0.0281 & 0.0264 \\
Share of R\&D employment in total employment & 0.0232 & 0.0527 & 0.0496 \\
Firm size (number of employees) & 429.6821 & 3649.5190 & 3644.7420 \\
Data from the Establishment History Panel: & & & 0.0178 \\
Share of employees aged less than 30 years (\%) & 17.1608 & 9.3881 & 8.9765 \\
Share of employees aged 30-49 years (\%) & 57.5660 & 9.3267 & 8.7179 \\
Share of employees aged 50 years or older (\%) & 25.2534 & 10.0994 & 9.6630 \\
Share of female employees (\%) & 30.1249 & 20.7646 & 20.6295 \\
Share of medium qualified employees (\%) & 61.5195 & 20.5359 & 2.7519 \\
Share of highly qualified employees (\%) & 6.0263 & 7.8487 & 3.3166 \\
Share of part-time employees (\%) & 18.1817 & 14.6017 & 2.9398 \\
\hline
\end{tabular}

Note: The data are from a balanced panel (4 years from 2003 to 2006) with a total of 16,900 yearly observations for 4,225 enterprises. For the definitions of the variables see text

\section{Estimation results}

Before we present the results of our econometric investigation we state explicitly that we are looking for correlations between the level of R\&D activities and the age and gender composition of the workforce, and not for causal effects. Evidently, the decision of a firm to invest in $\mathrm{R} \& \mathrm{D}$ activities and the decision to employ workers from certain groups (age or sex) are both endogenous. The link between both decisions can run in both directions-firms with an older workforce might be less innovative due to a negative effect of age on skill formation and on cognitive skills (as discussed in the introductory section) and innovative firms might decide to employ less older people for the same reasons. As pointed out in Sect. 2, the variation over time of R\&D intensity and the composition of the workforce is too small during the four year period we have data for to try to investigate the direction of causality. Furthermore, suitable instruments for a causal analysis are not available.

That said, the results of the fractional logit regressions for the proportion of R\&D outlays in total revenues are presented in Table 2. The first column contains the estimated coefficients, the second column their robust standard errors, and the third column the corresponding p-values for being significantly different from zero. In order to facilitate the interpretation, we have computed average marginal effects (fourth column), marginal effects at the means of all covariates (fifth column) and elasticities at the means of all covariates (sixth column). As the mean proportion of $R \& D$ outlays

a second step if the answer to the first step is "yes". The firm decides which amount of R\&D spending is optimal, and this amount can be either zero or positive (see the discussion in Ramalho et al. 2011, p. 27). in total revenues is only 1.11 percent, the estimated marginal effects look small at first glance. If we compute the elasticities, we can however see the economic importance of the workforce composition. A one percent higher share of employees 50 years or older is related to a 0.49 percent lower proportion of $\mathrm{R} \& \mathrm{D}$ outlays in total revenues, which is statistical significant at high levels. The middle age group of employees 30-49 years has however no significant coefficient. ${ }^{9}$ Furthermore, the results reveal that a one percent higher female share is significantly related to a 0.28 percent higher proportion of $R \& D$ outlays in total revenues. As one would expect for knowledge related outcomes, firms with a more qualified workforce have a higher proportion of R\&D outlays in total revenues, whereas firms with a higher share of part-time employees have a lower proportion of R\&D outlays in total revenues.

The results of the fractional logit regressions for the share of R\&D employment in total employment are presented in Table 3. The mean share of R\&D employment in total employment is only 2.32 percent so that the estimated marginal effects look again small at first glance. Thus, we focus on the elasticities. A one percent higher share of employees 50 years or older is significantly related to a 0.52 percent lower share of R\&D employment in total employment. The middle age group of employees 30-49 years has no significant effect. The results further reveal that a one percent higher

\footnotetext{
${ }^{9}$ As the choice of age groups is always arbitrary, our decision to focus on the three age groups $<30$ years, 30-49 years, and $>49$ years is driven by our preference for larger groups that have the advantage of more robust results (and by having a look in the literature). But we have also conducted a robustness check with eleven age groups that basically confirm our findings. These results are available upon request.
} 
Table 2 Fractional logit regressions for the proportion of R\&D outlays in total revenues

\begin{tabular}{lccrrrr}
\hline Explanatory variables & (1) Coefficient & $\begin{array}{l}\text { (2) Standard } \\
\text { error }\end{array}$ & (3) p-value & $\begin{array}{l}\text { (4) Average } \\
\text { marginal effect }\end{array}$ & $\begin{array}{l}\text { (5) Marginal } \\
\text { effect at means }\end{array}$ & $\begin{array}{l}\text { (6) Elasticity } \\
\text { at means }\end{array}$ \\
\hline Employees 30-49 years (\%) & -0.001691 & 0.005566 & 0.7610 & -0.000018 & -0.000009 & -0.0968 \\
Employees 50 years or older (\%) & -0.019652 & 0.004867 & $<0.0001$ & -0.000210 & -0.000101 & -0.4937 \\
Female employees (\%) & 0.009466 & 0.001966 & $<0.0001$ & 0.000101 & 0.000049 & 0.2837 \\
Medium qualified employees (\%) & 0.006972 & 0.001974 & $<0.0001$ & 0.000074 & 0.000036 & 0.4267 \\
Highly qualified employees (\%) & 0.052009 & 0.003691 & $<0.0001$ & 0.000555 & 0.000267 & 0.3118 \\
Part-time employees (\%) & -0.014284 & 0.003293 & $<0.0001$ & -0.000152 & -0.000073 & -0.2584 \\
Firm size (number of employees) & 0.000051 & 0.000020 & 0.0110 & $5.42 \mathrm{e}-07$ & $2.61 \mathrm{e}-07$ & 0.0217 \\
Firm size (squared) & $-3.74 \mathrm{e}-10$ & $2.17 \mathrm{e}-10$ & 0.0850 & $-3.99 \mathrm{e}-12$ & $-1.92 \mathrm{e}-12$ & -0.0050 \\
Constant & -8.205332 & 0.942781 & $<0.0001$ & & & \\
Pseudo $R^{2}$ (McFadden) & 0.1403 & & & & &
\end{tabular}

Note: Fractional logit regressions for proportion of R\&D outlays in total revenues. All models include dummy variables for years and 2digit-level industries. Robust standard errors for coefficients clustered at the firm level. The data are from a balanced panel (4 years from 2003 to 2006$)$ with a total of 16,900 yearly observations for 4,225 enterprises

Table 3 Fractional logit regressions for the share of R\&D employment in total employment

\begin{tabular}{lccrrrr}
\hline Explanatory variables & (1) Coefficient & $\begin{array}{l}\text { (2) Standard } \\
\text { error }\end{array}$ & (3) p-value & $\begin{array}{l}\text { (4) Average } \\
\text { marginal effect }\end{array}$ & $\begin{array}{l}\text { (5) Marginal } \\
\text { effect at means }\end{array}$ & $\begin{array}{l}\text { (6) Elasticity } \\
\text { at means }\end{array}$ \\
\hline Employees 30-49 years (\%) & 0.001420 & 0.004919 & 0.7730 & 0.000031 & 0.000017 & 0.0808 \\
Employees 50 years or older (\%) & -0.020856 & 0.004195 & $<0.0001$ & -0.000448 & -0.000243 & -0.5205 \\
Female employees (\%) & 0.005210 & 0.001854 & 0.0050 & 0.000112 & 0.000061 & 0.1551 \\
Medium qualified employees (\%) & 0.003722 & 0.001985 & 0.0610 & 0.000080 & 0.000043 \\
Highly qualified employees (\%) & 0.056255 & 0.004145 & $<0.0001$ & 0.001208 & 0.000654 & 0.3350 \\
Part-time employees (\%) & -0.014297 & 0.002958 & $<0.0001$ & -0.000307 & -0.000166 & -0.2569 \\
Firm size (number of employees) & 0.000040 & 0.000017 & 0.0200 & $8.50 \mathrm{e}-07$ & $4.60 \mathrm{e}-07$ & 0.0168 \\
Firm size (squared) & $-3.00 \mathrm{e}-10$ & $1.89 \mathrm{e}-10$ & 0.1120 & $-6.45 \mathrm{e}-12$ & $-3.49 \mathrm{e}-12$ & -0.0040 \\
Constant & -9.043343 & 0.949547 & $<0.0001$ & & & \\
Pseudo $R^{2}$ (McFadden) & 0.1594 & & & &
\end{tabular}

Note: Fractional logit regressions for share of R\&D employment in total employment. All models include dummy variables for years and 2digitlevel industries. Robust standard errors for coefficients clustered at the firm level. The data are from a balanced panel (4 years from 2003 to 2006$)$ with a total of 16,900 yearly observations for 4,225 enterprises

female share is significantly related to a 0.16 percent higher share of R\&D employment in total employment. Firms with a more qualified workforce have a higher share of $R \& D$ employment in total employment, whereas firms with a higher share of part-time employees have a lower share of $R \& D$ employment in total employment.

\section{Conclusion}

Overall, the results for the workforce composition variables do not differ noteworthy between both proxies for innovative firm behavior in the fractional logit regressions. Our estimates for innovative firm behavior reveal on average a negative correlation with older employees and a positive corre- lation with female employment. The first finding indicates a potential problem for innovative firms (and economies) that are faced with an aging workforce due to the ongoing demographic change. The second finding shows however a potential strategy to solve this problem, namely to activate female labor supply, which is still not exhausted if we look at the lower employment rates and working hours of women compared to men - at least in Germany (e.g., Humpert and Pfeifer 2013).

\section{Executive Summary}

Innovative activities are important for the performance of firms and the growth of the economy as a whole. This holds 
especially for firms from manufacturing industries in Germany. The manufacturing sector is known to be highly export intensive, and Germany is one of the leading actors on the world market for goods. International competitiveness of manufacturing firms depends to a high degree on the capability of firms to supply high-quality innovative products. Therefore, research and development (R\&D) activities that are important for continuous improvements of products and production processes are a decisive factor for the success of firms. That said, information on factors that are positively or negatively related to $R \& D$ activities of firms is important for both researchers and policy makers. This paper focuses on one aspect that is becoming more and more important not only for Germany but for other highly industrialized countries, too- the consequences of an ageing population and an ageing workforce for innovation activities of firms.

The effects of an aging workforce are usually analyzed in the context of productivity estimates that mostly indicate a negative effect of the oldest age groups on firm performance. In the context of innovations, we should also expect a negative correlation with age, because the literature about age-dependent skill formation suggests that age has a negative effect on human capital investments (e.g., due to decreasing amortization periods) and on cognitive skills such as intelligence, memory power, reasoning, creativity, and fluid problem-solving skills, which are important for innovative activities. Previous studies, which use firm level data, find indeed that (old) age has a negative effect on firms' innovation activities (e.g., product and process innovations, patents). The demographic change makes it also necessary to activate female labor supply. In order to analyze the effect of female employment on innovative activities, we include in our regression analysis the gender composition of a firm's workforce in addition the age composition of the workforce. We extend the literature by using newly available high quality official data for Germany. In addition to largely unbiased data obtained from administrative sources, the data set contains unique information such as the proportion of R\&D outlays in total revenues that has not been previously studied.

Our estimates for innovative firm behavior reveal on average a negative correlation with older employees and a positive correlation with female employment. A one percent higher share of employees 50 years or older is significantly related to a 0.52 percent lower share of $R \& D$ employment in total employment. The middle age group of employees 30 49 years has no significant effect. The results further reveal that a one percent higher female share is significantly related to a 0.16 percent higher share of R\&D employment in total employment. Firms with a more qualified workforce have a higher share of R\&D employment in total employment, whereas firms with a higher share of part-time employees have a lower share of R\&D employment in total employment. The first finding (a negative correlation of innovative firm behavior with older employees) indicates a potential problem for innovative firms (and economies) that are faced with an aging workforce due to the ongoing demographic change. The second finding (a positive correlation of innovative firm behavior with female employment) shows however a potential strategy to solve this problem, namely to activate female labor supply, which is still not exhausted if we look at the lower employment rates and working hours of women compared to men-at least in Germany. One drawback of our empirical analyses is, however, that we cannot rule out endogeneity problems such as reverse causality. Therefore, we can only look at the correlation between innovative firm behavior and the age and gender composition of the workforce. This limitation should be kept in mind when putting the results into perspective.

\section{Kurzfassung}

Innovationen sind von hoher Bedeutung für die Performance von Firmen und das Wachstum der Wirtschaft insgesamt. Dies gilt speziell für Firmen aus dem Verarbeitenden Gewerbe in Deutschland. Die deutsche Industrie ist bekannter Maßen sehr exportintensiv und Deutschland ist einer der wichtigsten Akteure auf dem Weltmarkt für Güter. Die internationale Wettbewerbsfähigkeit der Industrieunternehmen hängt stark von ihrer Fähigkeit ab, qualitativ hochwertige innovative Produkte anzubieten. Forschungsund Entwicklungsaktivitäten, die zu einer kontinuierlichen Verbesserung von Produkten und Produktionsprozessen beitragen, sind daher ein entscheidender Bestimmungsgrund für den Erfolg von Firmen. Damit haben Informationen über Faktoren, die positiv oder negativ mit dem Aufwand einer Firma für Forschungs- und Entwicklung (FuE) zusammen hängen, eine hohe Bedeutung sowohl aus betriebswirtschaftlicher als auch aus volkswirtschaftlicher und wirtschaftspolitischer Sicht. Dieser Beitrag konzentriert sich besonders auf einen Aspekt, der mehr und mehr nicht nur in Deutschland sondern auch in anderen hoch industrialisierten Ländern an Bedeutung gewinnt - die Konsequenzen aus einer alternden Erwerbsbevölkerung für die Innovationsaktivitäten von Firmen.

Die Auswirkungen einer alternden Belegschaft werden üblicher Weise im Zusammenhang mit Produktivitätsschätzungen untersucht, bei denen sich meistens ein negativer Einfluß der ältesten Gruppen auf die Firmenperformance zeigt. Im Zusammenhang mit Innovationen ist ebenfalls ein negativer Einfluß zu erwarten, denn die Literatur zu Alter und Qualifikationserwerb deutet darauf hin, dass mit zunehmendem Alter die Investitionen in Humankapital wegen der geringeren verbleibenden Amortisationsperiode abnehmen. Ferner werden kognitive Fähigkeiten wie Intelligenz, Gedächtnisleistung und Kreativität, die alle für 
Innovationsaktivitäten wichtig sind, mit zunehmendem Alter geringer. Frühere Studien auf der Basis von Firmendaten finden einen negativen Effekt eines hohen Belegschaftsalters auf Innovationsaktivitäten (Produkt- und Prozessinnovationen, Patente). Der demographische Wandel macht ferner eine gesteigerte Erwerbsbeteiligung von Frauen erforderlich. Zur Analyse der Effekte eines höheren Frauenanteils in der Belegschaft auf die Innovationsaktivitäten von Firmen enthält unser empirisches Modell neben Angaben zur Altersstruktur der Beschäftigten auch Angaben zur Zusammensetzung der Belegschaft nach Geschlecht. Wir liefern einen innovativen Beitrag zur Literatur durch die Verwendung von neu verfügbaren und qualitativ hochwertigen Daten der amtlichen Statistik für Deutschland. Diese Daten enthalten erstmals auch Angaben zu den Aufwendungen für Forschung und Entwicklung in den Firmen und zu den Beschäftigten in diesen Bereichen.

Unsere Schätzungen für das Innovationsverhalten der Firmen zeigen im Durchschnitt einen negativen Zusammenhang mit dem Anteil älterer Beschäftigter an der Gesamtbelegschaft und einen positiven Zusammenhang mit dem Frauenanteil. Ein um 1 Prozent höherer Anteil der Beschäftigten mit einem Alter von 50 oder mehr Jahren ist statistisch signifikant mit einem um 0.52 Prozent niedrigerem Anteil der FuE-Beschäftigten in der Firma verbunden. Die mittlere Altersgruppe der Beschäftigten zwischen 30 und 49 Jahren hat keinen Einfluß auf die FuE-Aktivitäten. Die Ergebnisse zeigen ferner, dass ein um 1 Prozent höherer Frauenanteil signifikant mit einem um 0.16 Prozent höheren Anteil der FuE-Beschäftigten zusammen hängt. Firmen mit einer besser qualifizierten Belegschaft haben einen höheren Anteil von FuE-Beschäftigten, während Firmen mit einem höheren Anteil an Teilzeitbeschäftigten weniger aktiv in FuE engagiert sind. Der erste Befund (eine negative Korrelation von Innovationsaktivitäten und älterer Belegschaft) zeigt ein potenzielles Problem für innovative Firmen (und Wirtschaften), die auf Grund des demographischen Wandels mit einem alternden Erwerbspersonenpotenzial konfrontiert sind. Der zweite Befund (eine positive Korrelation von Innovationsaktivitäten mit dem Anteil weiblicher Beschäftigter) deutet auf eine mögliche Strategie zur Lösung dieses Problems hin - die Steigerung der Erwerbsbeteiligung von Frauen, für die es in Deutschland noch breiten Raum gibt. Eine Schwachstelle unserer empirischen Analysen besteht darin, dass wir eine umgekehrte Kausalität von Innovationsaktivitäten auf Änderungen in der Belegschaftsstruktur nicht ausschließen können. Wir können nur Korrelationen untersuchen und keine Ursache-Wirkungszusammenhänge aufzeigen. Dies sollte bei einer Gesamteinschätzung unserer hier vorgestellten Befunde beachtet werden.

\section{References}

Biewen, E., Gruhl, A., Gürke, C., Hethey-Maier, T., Weiß, E.: Combined firm data for Germany-possibilities and consequences of merging firm data from different data producers. Schmollers Jahrb. Wirtsch.-Soz.wiss. (J. Appl. Soc. Sci. Stud.) 132(3), 361377 (2012)

Crépon, B., Duguet, E., Mairesse, J.: Research, innovation and productivity: an econometric analysis at the firm level. Econ. Innov. New Technol. 7(2), 115-158 (1998)

Fritsch, M., Görzig, B., Hennchen, O., Stephan, A.: Cost structure surveys for Germany. Schmollers Jahrb. Wirtsch.-Soz.wiss. (J. Appl. Soc. Sci. Stud.) 124(4), 557-566 (2004)

Hethey-Maier, T., Seth, S.: Das Betriebs-Historik-Panel (BHP) 1975-2008. Handbuch Version 1.0.2. Forschungsdatenzentrum der Bundesagentur für Arbeit im Institut für Arbeitsmarkt- und Berufsforschung, FDZ-Datenreport 04/2010. Nürnberg (2010). Download: http://doku.iab.de/fdz/reporte/2010/DR_04-10.pdf. Accessed 6.12.2011

Humpert, S., Pfeifer, C.: Explaining age and gender differences in employment rates: a labor supply side perspective. J. Labour Market Res. 46(1), 1-17 (2013)

Kaufman, A.S.: WAIS-III IQs, Horn's theory, and generational changes from young adulthood to old age. Intelligence 29, 131-167 (2001)

Papke, L.E., Wooldridge, J.M.: Econometric methods for fractional response variables with an application to $401(\mathrm{~K})$ plan participation rates. J. Appl. Econom. 11, 619-632 (1996)

Parrotta, P., Pozzoli, D., Pytlikova, M.: The nexus between labor diversity and firm's innovation. IZA discussion paper no. 6972 (2012)

Pfeifer, C., Wagner, J.: Age and gender composition of the workforce, productivity and profits: Evidence from a new type of data for German enterprises. IZA Discussion Paper No. 6381 (2012)

Pfeiffer, F., Reuß, K.: Age-dependent skill formation and returns to education. Labour Econ. 15, 631-646 (2008)

Ramalho, E.A., Ramalho, J.J.S., Murteira, J.M.R.: Alternative estimating and testing empirical strategies for fractional regression models. J. Econ. Surv. 25(1), 19-68 (2011)

Roberts, M.J., Vuong, V.A.: Empirical Modeling of R\&D Demand in a Dynamic Framework (2013). Mimeo, February

Schneider, L.: Alterung und technologisches Innovationspotential: eine Linked Employer-Employee Analyse. Z. Bevölk.wiss. 33(1), 3754 (2008)

Spengler, A.: The establishment history panel. Schmollers Jahrb. Wirtsch.-Soz.wiss. (J. Appl. Soc. Sci. Stud.) 128(3), 501-509 (2008)

Wagner, J.: Exports and firm characteristics in German manufacturing industries: new evidence from representative panel data. Appl. Econ. Q. 57(2), 107-143 (2011)

Wagner, J.: The quality of the KombiFiD-sample of enterprises from manufacturing industries: evidence from a replication study. Schmollers Jahrb. Wirtsch.-Soz.wiss. (J. Appl. Soc. Sci. Stud.) 132(3), 379-392 (2012)

Zühlke, S., Zwick, M., Scharnhorst, S., Wende, T.: The research data centres of the federal statistical office and the statistical offices of the länder. Schmollers Jahrb. Wirtsch.-Soz.wiss. (J. Appl. Soc. Sci. Stud.) 124(4), 567-578 (2004)

Prof. Dr. Christian Pfeifer studied economics and management at Leibniz University Hannover, Germany, and Maastricht University, Netherlands. He received his Diploma (Master equivalent) in 2003 and doctoral degree in 2007 from Leibniz University Hannover. From 2007 to 2009 he was a Post-Doc at Leibniz University Hannover and University of California Berkeley. Since September 2009 he is Professor (W1) of Economics at Leuphana University Lüneburg. His research focus is on empirical labour and personnel economics. 
Prof. Dr. Joachim Wagner is Professor of Economics at the Leuphana University Lüneburg. He is a research fellow at IZA and an editor of Schmollers Jahrbuch/Journal of Applied Social Science Studies, Jahrbücher für Nationalökonomie und Statistik/Journal of Economics and Statistics and the Journal for Labour Market Research/Zeitschrift für ArbeitsmarkForschung. Furthermore, he is a member of the Ger- man Data Forum (RatSWD). He published widely in economics journals; the topics include international firm activities and issues related to labor markets and industrial relations. Most of his papers use longitudinal data for firms for micro-econometric investigations. 